\title{
AN ECONOMIC ANALYSIS OF GOVERNMENT REVENUE AND EXPENDITURE IN NEPAL
}

\author{
Krishna Raj Acharya*
}

\begin{abstract}
The government revenue and expenditure are two key words frequently discussed in economic literature. In the context of Nepal both are increasing but increase in expenditure is rapid than the increase in revenue. Government expenditure if not matched with government income, it may have accompanied with economic evils. Revenue collection if not increased or managed in time, the amount of public debt will increase more rapidly in the future. In this connection, the volume of expenditure is increasing year after year due to the increased role of government in the economy. Revenue mobilization in fiscal year 2012/13 and 2013/14 hovered around 21 percent while that in FY 2014/15 was just 13.8 percent. Contribution of revenue to the total income in FY 2011/12 had remained at 84.85 percent while it grew to 88.65 percent, 89.86 percent and 90.11 percent respectively in the fiscal years from 2012/13 2013/14, and 2014/15 respectively. Hence the volume of public expenditure is increasing rapidly year after year. In FY2012/13 increase in public expenditure was 5.74 percent per annum which reached to 22.18 per annum in year 2014/15.
\end{abstract}

Key words: Government revenue, government expenditure, fiscal deficit, government debt

\section{INTRODUCTION}

Government revenue is money received by a government in certain time period especially in a year from various sources. Especially government receives their income from tax and non-tax sources. It is also known as the detail plan of the government income. It is an important tool of the fiscal policy of the government and is the opposite factor of government spending. Revenues earned by the government are received from sources such as taxes levied on the incomes and wealth accumulation of individuals and corporations and on the goods and services produced, exports and imports, non-taxable sources such as government-owned corporations'

* Dr. Acharya is Reader in Economics, Ratna Rajya Laxmi Campus, Department of Economics, Bhrikuti Mandap, TU. 
incomes, central bank revenue and capital receipts in the form of external loans and debts from international financial institutions.

Governmentexpenditure includes all government spending like consumption, investment, and transfer payments. In national income accounting the acquisition by governments of goods and services for current use in certain time period, to directly satisfy the individual or collective wants or needs of the society or community, is classified as government final consumption expenditure. Government acquisition of goods and services intended to create future benefits, such as resilient infrastructure investment or research spending in various sectors, is categorized as government investment (government gross capital formation). These two types of government spending, on final consumption and on gross capital formation, together constitute one of the major components of gross domestic product of a nation in the world ( CBS, 2011 a).

Government spending can be financed by government borrowing, seignior age, or taxes. Changes in government spending are a major component of fiscal policy used to stabilize the macroeconomic indicators in a nation.

The sources of finance used by the central government are mainly taxes paid by the public. Government revenue in FY 2015/16 was at Rs. 587.94 billion which was 31.14 percent higher than that of the real income of FY 2014/15. The public income in FY 2014/15 had stood at to be Rs. 448.33 billion. The revenue of FY 2014/15 was 13.12 percent higher than that of FY 2013/14. Likewise, such revenue of FY 2013/14 was increased by 18.68 percent to Rs. 396.31 billion. This revenue of FY 2014/15 is 13.12 percent higher than that of FY 2013/14. Likewise, such revenue of FY 2013/14 had increased by 18.68 percent to Rs. 396.31 billion as compared to its preceding fiscal year (Economic Survey, 2015/16). Of the total budget of Rs 819.46 billion earmarked for the current fiscal year 2015/16, recurrent expenditure accounted for 59.1 percent, 25.5 percent allocated for capital expenditure while 15.4 percent was allotted for fiscal arrangement. In the previous fiscal year 2014/15, of the gross real expenditure Rs. 531.55 billion, recurrent expenditure was 63.86 percent, capital expenditure was 16.71 percent while 19.43 percent was allotted for fiscal arrangement. In the developed countries, revenue and expenditure found to be less or more stable. However in the developing countries, the volume of public expenditure seems to be very high to compare with revenue. Domestic sources of revenue in the developing countries are very limited due to the 
poor economic performance. However, the expenditure is increasing due to expanding activities and role of the governments. As a result, the level of investment is found to be very low in developing countries. Similarly, there is lack of investment friendly environment because of economic, social and political instability. Consequently, per capita income of the people is limited to be less than $\$ 500$. Basically, low income leads towards low level of government expenditure in the developing countries.

\section{OBJECTIVE}

The purpose of this article is to find the volume and structures of government expenditures of Nepal. Even it has some specific objectives listed as below:

- To identify the change in government income from fiscal year 2011/12 to $2015 / 16$,

- To analyze the government expenditure in the same period, and

- To explore the gap between government revenue and expenditure in fiscal years 2011/12 to 2015/2016.

\section{METHODOLOGY}

The article has used secondary data published by the government of Nepal from fiscal years 2011/12 to 2015/16.The data is of five fiscal years $2011 / 12$ to $2015 / 16$. Available literature and data are analyzed according to the objectives. Hence, National Planning commission, Ministry of Finance and Central Bureau of Statistics are taken into consideration. Similarly, 'Excel 2007', 'SPSS' and 'R' are major tools of analysis.

\section{ANALYSIS AND RESULT}

Government income and expenditure both are powerful fiscal instruments to attain various economic objectives like price stability and proper allocation of resources. In this connection, government income and expenditure both are increasing in recent years but increase in expenditure is more rapid than the increase in government revenue. This has resulted however found to be long run negative impact on economic development in a sustainable manner.

\section{Government income from FY 2011/12 to 2015/16}

Revenue mobilization of Rs. 475.01 billion with Rs. 427.01 billion collected from tax revenue and Rs.48 billion from non-tax revenue was estimated for the fiscal year 2015/16 that means the shares of tax and nontax 
revenues to the total revenue stood at 87.7 percent and 12.3 percent with revenue mobilization of Rs.405.86billions in previous fiscal year 2014/15. The shares of tax and non-tax revenues to the total revenue mobilization from the fiscal years 2011/12 to 2013/14 remained close to 87 percent and 13 percent respectively while such shares are expected to remain at 89.89 percent and 10.11 percent in current fiscal year 2015/16.

Contribution of goods and services based tax has attained the top position in the tax revenue collected between FY 2011/12 and the current fiscal year with about 45 percent share to the total revenue. During this period, contribution of income, profit and capital gains taxes, and that of foreign trade based tax to total revenue remained close to 21 percent and 18 percent respectively. The share of property tax in the form of direct tax to the total revenue collected in fiscal years from 2011/12 to 2014/15 remained below 2 percent while such share went up to 2.3 percent in previous fiscal year. Likewise, the property tax amounting Rs. 12.04 billion is expected to be mobilized in current fiscal year contributing 2.54 percent to the total revenue. The share of other taxes to the revenue mobilization in the fiscal years from 2011/12 to 2015/16 has remained about 0.5 percent (Economic Survey, 2015/16).Details of government income from fiscal year 2011/12 to 2015/16 can be listed as follows (Table 1):

Table 1: Details of Government Income (In Rs 10 Millions)

\begin{tabular}{|c|c|c|c|c|c|}
\hline $\begin{array}{c}\text { Fiscal } \\
\text { Year }\end{array}$ & $\begin{array}{c}\text { Tax } \\
\text { Revenue }\end{array}$ & $\begin{array}{c}\text { Non Tax } \\
\text { Revenue }\end{array}$ & $\begin{array}{c}\text { Other } \\
\text { Sources }\end{array}$ & $\begin{array}{c}\text { Total } \\
\text { Government } \\
\text { Income }\end{array}$ & $\begin{array}{c}\text { \% Change in } \\
\text { Government } \\
\text { Income }\end{array}$ \\
\hline $\mathbf{2 0 1 1 / 1 2}$ & 21172.2 & 3265.1 & 4360.9 & 28798.3 & ---- \\
\hline $\mathbf{2 0 1 2 / 1 3}$ & 25921.4 & 3680.6 & 3790.5 & 33392.7 & 15.98 \\
\hline $\mathbf{2 0 1 3 / 1 4}$ & 31244.1 & 4417.9 & 4026.3 & 39688.4 & 18.85 \\
\hline $\mathbf{2 0 1 4 / 1 5}$ & 35595.5 & 4991.1 & 4454.5 & 45041.2 & 13.48 \\
\hline $\mathbf{2 0 1 5 / 1 6 *}$ & 42701.1 & 4800.1 & 11292.9 & 58794.1 & 30.53 \\
\hline
\end{tabular}

Source: Financial Controllers General Office and Budght Speech of Current F/Y 2015/16

Note: * indicates estimated figure

In the Table, there is increase in income annually. In fiscal year 2012/13, increase in income is 15.98 percent and in the last fiscal year it is projected to be 30.53 percent. In other sources, there are foreign grants, 
principle repayment receipt and irregularities recovery ( Table 1). Of the total government income estimated for FY 2015/16, revenue was expected to have a share of 80.80 percent with mobilization of Rs. 475.01 billion, which was 17.03 percent higher than that of preceding fiscal year 2014/15. Revenue mobilization in fiscal year 2012/13 and 2013/14 covered around 21 percent while that in FY 2014/15 it was just 13.8 percent. Contribution of revenue to the total income in FY 2011/12 had remained at 84.85 percent while it grew to 88.65 percent, 89.86 percent and 90.11 percent in the fiscal years from 2012/13 2013/14, and 2014/15 respectively. It was an arduous task to mobilize revenue at the desired level owing to uncomfortable environment that has resulted from devastating earthquake of April, 2015 and subsequent aftershocks, about five-month long border obstructions since August last year, low agricultural production due to adverse climate causing some erosion on demand side of the economy, and shrunken economic activities (Economic Survey, 2015/16). The graphical presentation of government income of the fiscal years 2011/12 to 2015/16 was as below:

Graph 1: Government Income from Fiscal Year 2011/12 to 2015/1

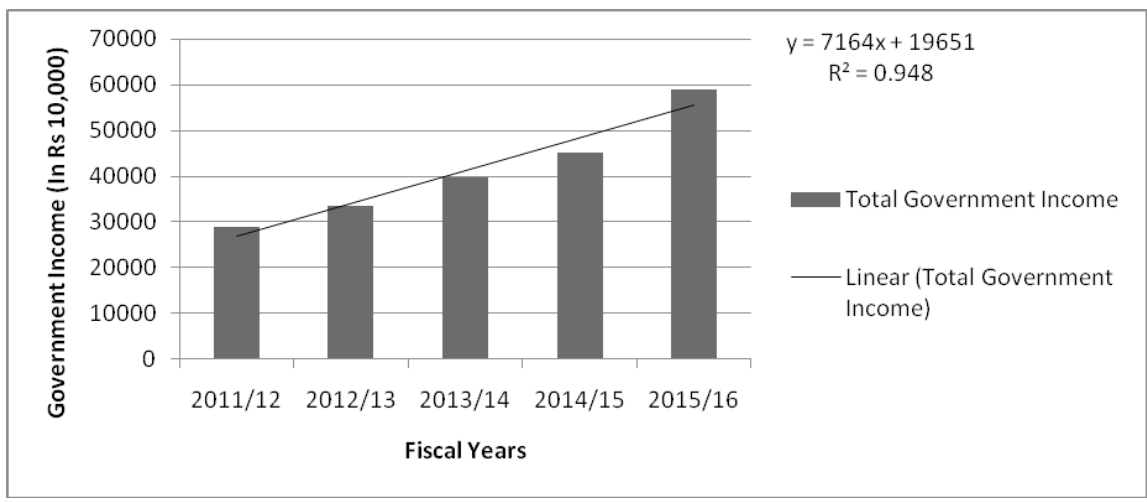

Income received by the government was increasing by a linear trend. The value of $\mathrm{R}^{2}$ was 0.98 indicates that there is association between fiscal year and government income collection.

\section{Government Expenditure from FY 2011/12 to 2015/16}

Government expenditure is an important fiscal tool to drive an economy in a desired direction. If this tool is handled properly and efficiently, a nation can get rid of various economic problems. In the present time, the volume of public expenditure is increasing due to widening role of governments for public welfare schemes. 
Of the total budget of Rs. 819.46 billion earmarked for the current fiscal year 2015/16, recurrent expenditure accounted for 59.1 percent, 25.5 percent allocated for capital expenditure while 15.4 percent was allotted for fiscal arrangements. In the previous fiscal year 2014/15, of the gross real expenditure Rs. 531.55 billion, recurrent expenditure was 63.86 percent, capital expenditure stood at 16.71 percent while 19.43 percent was allotted for fiscal arrangement (Economic Survey, 2015/16). The detail of government expenditure in the fiscal year 2011/12 to 2015/16 was increasing inconsistently.

Table 2: Details of Government Expenditure

(In Rs 10 Millions)

\begin{tabular}{|c|c|c|c|c|c|}
\hline $\begin{array}{c}\text { Fiscal } \\
\text { Year }\end{array}$ & $\begin{array}{c}\text { Recurrent } \\
\text { Expenses }\end{array}$ & $\begin{array}{c}\text { Capital } \\
\text { Expenses }\end{array}$ & $\begin{array}{c}\text { Other } \\
\text { Expenses }\end{array}$ & $\begin{array}{c}\text { Total } \\
\text { Government } \\
\text { Expenses }\end{array}$ & $\begin{array}{c}\text { \% } \\
\text { Change in } \\
\text { Expenses }\end{array}$ \\
\hline $\mathbf{2 0 1 1 / 1 2}$ & 243466 & 5139.1 & 4431.7 & 33916.8 & ----- \\
\hline $\mathbf{2 0 1 2} / \mathbf{1 3}$ & 24745.5 & 5459.8 & 5658.4 & 35863.8 & 5.74 \\
\hline $\mathbf{2 0 1 3 / 1 4}$ & 30353 & 6669.5 & 6483.1 & 43505.5 & 21.30 \\
\hline $\mathbf{2 0 1 4 / 1 5}$ & 33940.7 & 8884.3 & 10330.4 & 53155.4 & 22.18 \\
\hline $\mathbf{2 0 1 5} / \mathbf{1 6}^{*}$ & 48426.6 & 20887 & 12631.7 & 81946 & 54.16 \\
\hline
\end{tabular}

Source: Financial Controllers General Office and Budght Speech of Current F/Y 2015/16

Note: * indicates estimated figure

The volume of public expenditure was increasing slightly or rapidly year after year. In FY2012/13 increase in public expenditure was 5.74 percent per annum but in the fiscal year 2014/15, it was increased by 22.18per cent per annum (Table 2).

Graph 2: Government Expenditures from Fiscal Year 2011/12 to 2015/16

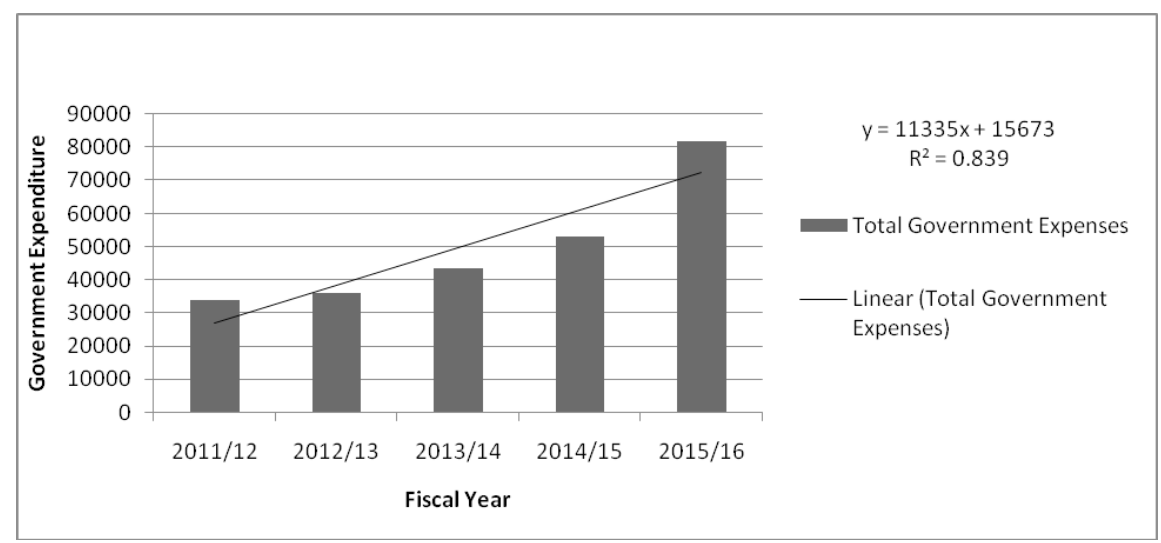


The volume of public expenditure is increasing year after year. Hence government expenses were increasing in a linear way whereas the change in revenue was not increasing to that it might be threat for the development of the nation. The demand of public expenditure has continued to grow for expediting the pace of development and construction works and meeting peoples 'broad aspirations. The requirement of public expenditure will certainly escalate in the process of adopting federal governance system while promulgating new constitution. Maintaining balance among public expenditure's demand, need and availability has been a complex task (Economic Survey, 2013/14). The share of revenue mobilization to GDP was close to 20 percent. Such ratio generally stands at 35 percent in countries advancing towards development. The task of mobilizing revenue in accordance with its viability remains a challenge (Economic Survey, 2015/16).Recurrent expenditure generally occupies one-fourth share in Nepal's total public expenditure while the share of capital expenditure shares was merely 15 percent in total. Though recurrent expenditure complies with estimation, capital expenditure seems to be remained below par. Despite fiscal deficit being executed to optimally mobilize public resources, budget surplus was likely to repeat at the end of the every fiscal year which has posed challenge to attest the effectiveness of capital expenditure.

\section{Gap between government revenue and expenditure in fiscal year 2011/12 to 2015/2016}

Maximum utilization of financial instruments by making the economy vibrant is a must to achieve sustainable, broad based and high economic development. Aside from generating revenue potentials, resources for the large projects that could bring effective changes in development scenario through the organized, effective and efficient mobilization of various sources could be guaranteed. There are two string fiscal tools for a government to stabilize the economy; government income (basically tax) and government expenditure. There should be balance between these two fiscal instruments. In Nepal, government expenditure is greater than the government income so that fiscal gap is negative (Table 3 ). 
Table 3: Government Income and Expenditure of Fiscal Year 2011/12 to 2015/16

\begin{tabular}{|c|c|c|c|}
\hline $\begin{array}{c}\text { Fiscal } \\
\text { Year }\end{array}$ & $\begin{array}{c}\text { Total Government } \\
\text { Income }\end{array}$ & $\begin{array}{c}\text { Total Government } \\
\text { Expenses }\end{array}$ & Fiscal Gap \\
\hline $\mathbf{2 0 1 1 / 1 2}$ & 28798.3 & 33916.8 & -5118.5 \\
\hline $\mathbf{2 0 1 2 / 1 3}$ & 33392.7 & 35863.8 & -2471.1 \\
\hline $\mathbf{2 0 1 3 / 1 4}$ & 39688.4 & 43505.5 & -3817.1 \\
\hline $\mathbf{2 0 1 4 / 1 5}$ & 45041.2 & 53155.4 & -8114.2 \\
\hline $\mathbf{2 0 1 5 / 1 6 *}$ & 58794.1 & 81946 & -23151.9 \\
\hline
\end{tabular}

Source: Financial Controllers General Office and Budght Speech of Current F/Y 2015/16

Note: $*$ indicates estimated figure

There was a gap between government income and expenditure. Fiscal gap was seemed to be widening year after year. This imbalance should be corrected in time. Income was increasing ata slow rate that means public had low capacity to pay tax.

Graph 3: Government Income and Expenditures from Fiscal Year 2011/12 to $2015 / 16$

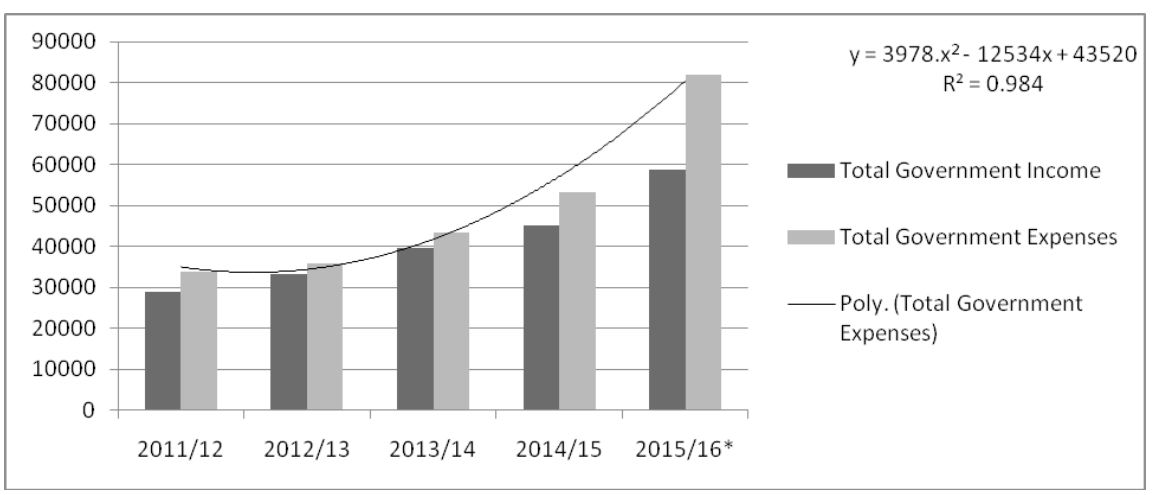

Public expenditure was increasing in faster pace than that of government income. Such type of fiscal condition cannot be experienced in the context of developed countries in the world. The relationship between government expenditure and income can be analyzed with the help of " $R$ " software. 


\section{Call:}

$\operatorname{lm}($ formula $=$ Total. Government. Expenses $\sim$ Total. Government. Income,

$$
\text { data }=\text { my data) }
$$

Residuals:

$$
\begin{array}{lllll}
1 & 2 & 3 & 4 & 5
\end{array}
$$

$4620-1018-3771-29583127$

Coefficients:

$$
\text { Estimate Std. Error } t \text { value } \operatorname{Pr}(>|t|)
$$

$$
\text { (Intercept) } \quad-1.825 \mathrm{e}+047.819 \mathrm{e}+03 \quad-2.334 \quad 0.10178
$$

Total.Government.Income1.651e+001.842e-01 $8.9610 .00293 * *$

$--$

Signif. codes: 0 ‘***’ 0.001 '**’ 0.01 '*’ 0.05 ' ${ }^{\prime} 0.1$ ' ' 1

Residual standard error: 4287 on 3 degrees of freedom

Multiple R-squared: 0.964， Adjusted R-squared: 0.952

F-statistic: 80.3 on 1 and 3 DF, p-value: 0.002933

Source: Based on data analysis through R software

This analysis helps to draw a conclusion that there was an association between government expenditure and government income. Government expenditure was assumed to be dependent in this analysis and income was an independent variables. One rupee increase in government was accompanied with 96 paisa increased in the government expenditure. When same data was analyzed through Excel 2007 software: 
60 AN ECONOMIC ANALYSIS OF GOVERNMENT REVENUE AND ...

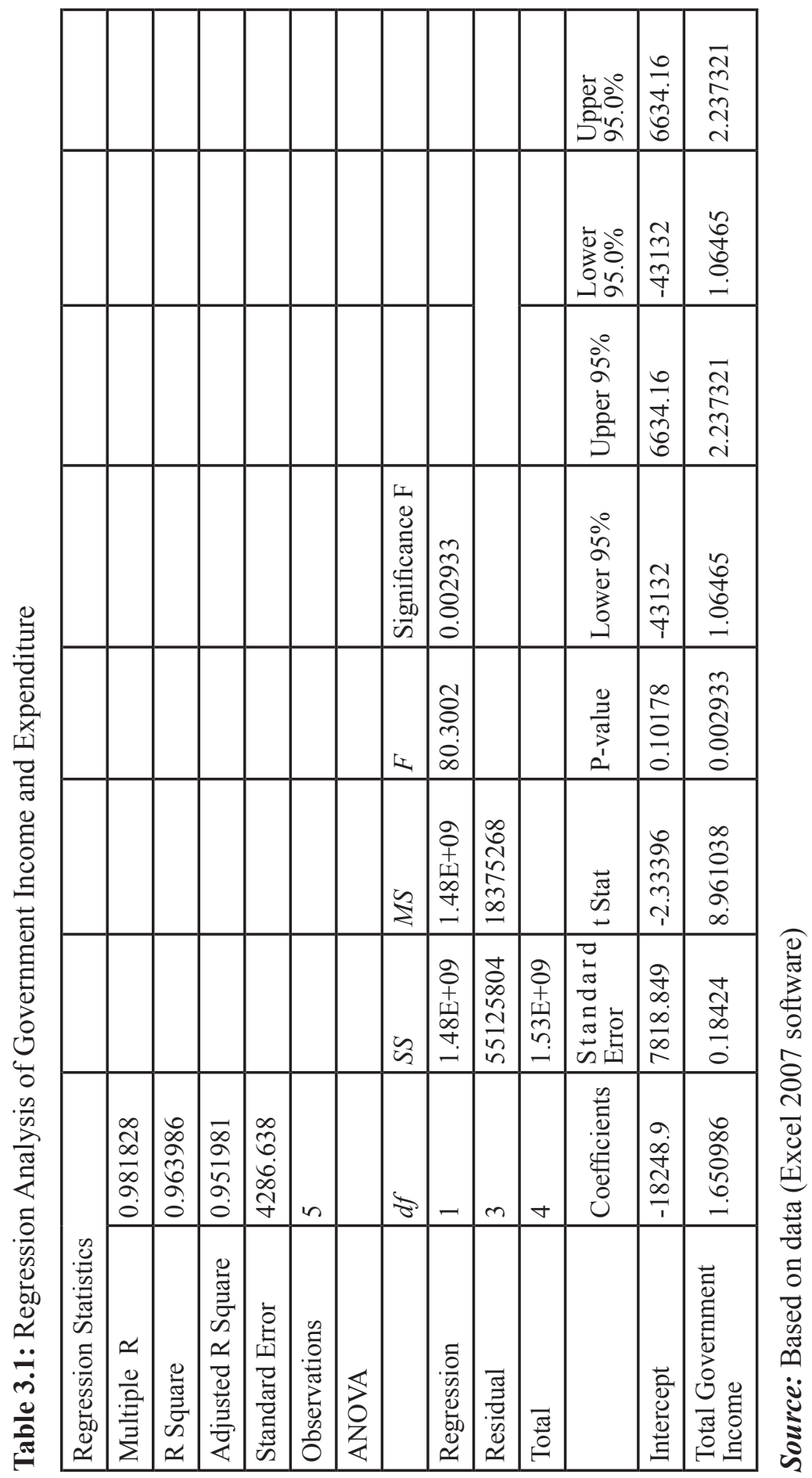


There was a close association between government expenditure and government income. The value of $R^{2}$ is 0.96 and the value of $p=0.0029$ (p value, Table 3.1).

\section{Causes of low government revenue and revenue gap}

Tax collection is a main source of government income however it was limited due to very narrow tax base. Tax payments tend to be concentrated only among a few taxpayers in South Asia. In India only 3 percent of the population pays personal income tax, with the figure even lower at about 1 percent in Bangladesh, Nepal, and Pakistan. A plethora of exemptions also exist, which have made tax systems more complex and may have contributed to the emergence of vested interests to resist further reforms.

Similarly, south Asian countries typically rank low on the common yardsticks of efficient tax administration. For instance, time spent preparing and paying taxes for a typical firm in South Asia was more than 300 hours, compared to 200 hours in East Asia and 175 hours in advanced countries (Shaw, 1889).

In this connection, previous research has shown that higher shares of agriculture and service sectors in GDP are negatively correlated with revenue to GDP ratios in developing countries, as was poor governance. This was particularly relevant for larger South Asian Countries, where agriculture has historically been under-taxed, while service sectors are also relatively large. Other factors that might impinge on low revenue mobilization include low literacy rates, large rural populations, large informal economies, and poor governance. In addition, the financial sector is underdeveloped in South Asian Countries with the implication that financial transactions occur in cash, abetting tax evasion. Indeed countries that have succeeded in increasing the size of their financial sector in the past decade (Bhutan, Maldives, and Nepal) have also been managed to increase their tax ratios. Gap between public revenue and expenditure is a fiscal issue that basically chronic in least developed countries in the world. Revenue administration should be strong and broad based so that there is less chances of revenue leakage. Tax base and rate should be reformed in such a way that revenue should be maximum accompanied with no increase in gap between rich and poor. Government expenditure should be prioritized in the areas where capital output ratio at least equal (CBS, 2011). Development activities should be directed towards productive capacity enhancement rather than the 


\section{2}

AN ECONOMIC ANALYSIS OF GOVERNMENT REVENUE AND ...

interest of donor agencies. The government should be wise for the proper, effective and efficient utilization of scarce resources of underdeveloped countries in the world. Lowering the gap could have a positive effect in the national economy for low dependency on foreign sources. It also is useful to accelerate the pace of domestic capital formation and ultimately higher, sustainable and broad-based growth rate.

\section{CONCLUSION}

Government income estimated for FY 2015/16, revenue was expected to have a share of 80.80 percent with mobilization of Rs. 475.01 billion, which was 17.03 percent higher than that of preceding fiscal year 2014/15. Revenue mobilization in fiscal year 2012/13 and 2013/14 hovered around 21 percent while that in FY 2014/15 was just 13.8 percent. Contribution of revenue to the total income in FY 2011/12 had remained at 84.85 percent while it was 88.65 percent, 89.86 percent and 90.11 percent respectively in the fiscal years from 2012/13 2013/14, and 2014/15. Hence the volume of public expenditure was increasing rapidly year after year. In the FY2012/13 the increment in public expenditure was 5.74 percent per annum which reached to 22.18 per annum in the FY 2014/15. There is a gap between government income and expenditure. Fiscal gap has been widening year after year. This imbalance should be corrected properly in time. Government revenue is increasing at slower rate. Hence, the taxable capacity of the nation should be strengthen.

\section{WORKS CITED}

CBS, (2011a). Poverty in Nepal. Kathmandu: National Planning Commission, Government of Nepal.

- - - (2011b). Nepal living standard survey, vol I \&2, Kathmandu: National Planning Commission, Government of Nepal.

Ministry of Finance (2012). Economic survey. Kathmandu: Government of Nepal.

- - - (2013). Economic survey. Kathmandu: Government of Nepal.

- - - (2014). Economic survey. Kathmandu: Government of Nepal.

- - - (2015). Economic survey. Kathmandu: Government of Nepal.

- - - (2016). Economic survey. Kathmandu: Government of Nepal.

- - - (2015, 2016). Budget speech. Kathmandu: Government of Nepal.

Shaw, A. (1889). Municipal government in Britain. Political Science Quarterly, 4(2), pp.197-229. 